\title{
IMPACTS OF REMITTANCES ON FOREIGN DIRECT INVESTMENT IN SOUTH EAST ASIA - AN EMPIRICAL INVESTIGATION
}

\author{
PHAM DINH LONG \\ Ho Chi Minh City Open University, Vietnam - long.pham@ou.edu.vn \\ NGUYEN VAN DUC \\ Thaison Company, Vietnam - nguyenvanduc.1989@gmail.com
}

(Received: August 08, 2017; Revised: September 21, 2017; Accepted: October 31, 2017)

\begin{abstract}
This study investigates the effects of remittances on attracting foreign direct investment flows to South East Asia. Using a balanced panel data set for seven countries in the 2000-2013 period, we find that remittances have a direct positive impact on attracting FDI. Significantly, the result also shows a negative correlation between remittances and FDI attraction in countries with low per capita income and small market size.
\end{abstract}

Keywords: Foreign direct investment; Market size; Remittances; South East Asia.

\section{Introduction}

In developing countries, FDI has not only increased but also become one of the most important sources of development finance. FDI positively affects economic growth so it is not surprising that most developing countries adopt policies to attract FDI. According to World Bank (2014), FDI leads in the proportion of external capital flows to the developing country, followed by remittances and ODA, and this cash flow is expected to rise steadily over the years.

\begin{tabular}{|l|l|l|l|l|l|l|l|l|l|l|}
\hline & 2004 & 2005 & 2006 & 2007 & 2008 & 2009 & 2010 & 2011 & 2012 & 2013 \\
\hline Remittance & 159 & 192 & 227 & 278 & 325 & 307 & 325 & 351 & 404 & 436 \\
\hline FDI & 208 & 276 & 346 & 514 & 593 & - & 637 & 735 & 703 & - \\
\hline ODA & 79 & 108 & 106 & 107 & 128 & 120 & 131 & 141 & 133 & - \\
\hline
\end{tabular}

Source: World Bank data, World Bank migration and remittances fact book 2014

The impressive increase in the FDI inflows and its benefits to the economy have prompted much research to study its factors and multidimensional impacts on the economy. Among them include research on the effects of exchange rate on FDI (Barrel \& Pain, 1996; Cushman, 1985 \& Pain, 2003), the relationship between labor costs and FDI (Culem, 1988; Cushman, 1987; Love \& Lagehidalgo, 2000); the political aspects and FDI (Haggard, 1989; Tuman \& Emmert, 2004); and market size and FDI (Barrel \& Pain, 1996; \& Love \& Lage-Hidalgo, 2000)

Among factors attracting FDI in the host country, remittances has been one of the most influential factors. According to UNCTAD (2012), remittances to ASEAN increased from $\$ 11$ billion in 2000 to $\$ 52.6$ billion in 2013 . Remittances contributions to the economy as a source of national income to help fight poverty, increase human capital, provide capital for investments in households or small 
and medium businesses, directly expand market size, stimulate aggregate demand of the economy, and promote FDI flows to meet consumer and importing demands.

In the study, we use a balanced panel data set from ASEAN countries during 2000-2013 period. The main objective is to empirically investigate the relationship between remittances and FDI inflows. In addition to directly assessing the impact of remittance flows on FDI, the article also evaluates the effectiveness of complementarity between remittances and per capita GDP in FDI receptor countries.

The research is then organized as follows: Section 2 providing literature review of previous theoretical and empirical works, Section 3 presenting the methodology and data, Section 4 showing empirical results; and the conclusion.

\section{Literature review}

Remittance is an important source of external financing for developing countries and considered as part of the recipient individuals' disposable income. Glytsos (2005) adds remittances to GDP to construct a type of host country disposable income to capture the demand effect of remittances on consumption, investment and imports. He finds a significant positive effect of this national income on consumption. Accordingly, it seems that remittances raise the demand for goods and services of an economy through increasing disposable income, and thus, raise the host country's aggregate demand

The effect of remittances on the economy is mixed. Anyanwu (2011) analyzes determinants of foreign direct investment in African countries between 1980 and 2007. He finds that remittance has a very significantly positive impact on attracting FDI inflows. The author argues that the rising remittance inflows will contribute to reducing poverty and expand consumer demand, and hence attract FDI inflows. Besides, remittances sometimes exceed the flows of official development assistance (ODA) and FDI. By using other aspect, Basnet and Upadhyaya (2014) find that households spend a significant portion of remittances investing in health and education and that human capital is one of the main determinants of foreign direct investment. Remittances have a great impact on attracting FDI through the development of human capital. Specially, Garcia-Fuentes et al (2016) investigate the effect of remittances on attracting foreign direct investment using the panel data for 15 countries in Latin America and the Caribbean (LAC) in the 1983-2010 period. They apply OLS and GMM-IV with many variables include remittances to GDP, per capita GDP, imports to GDP, exchange rate, average salary in the host country and recipient country of investment, inflation, and FDI in the past. The results show positive impact and importance of remittances to FDI flow in LAC. They further conclude that the effect of remittance on FDI depends on the level of per capita GDP in the host country. If a country's per capita GDP passes a certain threshold, the impact of remittances on FDI is positive. Otherwise such impact will be negative. This threshold is necessary for a country to benefit from the positive impact of remittances and FDI.

\section{Methodology and data The model}

This study uses the cost minimization model introduced by Bajo-Rubio and SosvillaRivero (1994) to analyze the inflows of FDI to ASEAN. This approach relates the FDI undertaken by a multinational firm (MNF) to cost minimization which allows deriving the optimal capital input for investing abroad. The model assumes that the MNF decides first on whether or not to undertake FDI which requires a decision on the output level in the foreign country. Once the firm's decision on FDI is positive, total costs of production are 
defined as a function of costs of production in both the MNF-home and MNF-foreign plants. Total costs are given by:

$$
\mathrm{TC}=\mathrm{c}_{\mathrm{h}}\left(\mathrm{q}_{\mathrm{h}}\right) \mathrm{q}_{\mathrm{h}}+\mathrm{c}_{\mathrm{f}}\left(\mathrm{q}_{\mathrm{f}}\right) \mathrm{q}_{\mathrm{f}}
$$

where TC is total costs, $c_{h}$ and $q_{h}$ are unit costs and output level in the home plant, $\mathrm{c}_{\mathrm{f}}$ and $\mathrm{q}_{\mathrm{f}}$ are unit costs and output level in the foreign plant, subscripts $\mathrm{h}$ and $\mathrm{f}$ are for home and foreign. The constraint for total cost minimization is given by total output demand as

$$
\mathrm{TD}=\mathrm{q}_{\mathrm{h}}+\mathrm{q}_{\mathrm{f}}
$$

Then the Lagrangian function is defined as

$\mathrm{L}=\mathrm{c}_{\mathrm{h}}\left(\mathrm{q}_{\mathrm{h}}\right) \cdot \mathrm{q}_{\mathrm{h}}+\mathrm{c}_{\mathrm{f}}\left(\mathrm{q}_{\mathrm{f}}\right) \mathrm{q}_{\mathrm{f}}+\lambda\left(\mathrm{TD}-\mathrm{q}_{\mathrm{h}}-\mathrm{q}_{\mathrm{f}}\right)(3)$

The first condition for cost minimization problem is given by

$$
\begin{aligned}
& \partial \mathrm{L} / \partial \mathrm{q}_{\mathrm{h}}=\mathrm{c}^{\prime}{ }_{\mathrm{h}}\left(\mathrm{q}_{\mathrm{h}}\right) \cdot \mathrm{q}_{\mathrm{h}+} \mathrm{c}_{\mathrm{h}}\left(\mathrm{q}_{\mathrm{h}}\right)-\lambda=0 \\
& \partial \mathrm{L} / \partial \mathrm{q}_{\mathrm{f}}=\mathrm{c}^{\prime}{ }_{\mathrm{f}}\left(\mathrm{q}_{\mathrm{f}}\right) \cdot \mathrm{q}_{\mathrm{f}+} \mathrm{c}_{\mathrm{f}}\left(\mathrm{q}_{\mathrm{f}}\right)-\lambda=0 \\
& \partial \mathrm{L} / \partial \lambda=\mathrm{TD}-\mathrm{q}_{\mathrm{h}}-\mathrm{q}_{\mathrm{f}}
\end{aligned}
$$

where $\quad c^{\prime}{ }_{h}=\partial c_{h} / \partial q_{h}$ and $\quad c^{\prime}{ }_{f}=\partial c_{f} / \partial q_{f}$. Equations (4) and (5) are marginal costs in the home and foreign plants respectively. Equating (4) and (5) are solving for home output and then substitutes this result into equation (6) yields equilibrium output in the foreign plant. Therefore, foreign production is given as

$$
\mathrm{q}_{\mathrm{f}}=Q_{1} \mathrm{TD}+Q_{2}\left(\mathrm{c}_{\mathrm{h}}-\mathrm{c}_{\mathrm{f}}\right)
$$

where $Q_{1}=c^{\prime}{ }_{h} /\left(c^{\prime}{ }_{h}+c^{\prime}{ }_{f}\right)$ and $Q_{2}=1 /\left(c^{\prime}{ }_{h}+c^{\prime}{ }_{f}\right)$ are assumed to be positive. Equation (7) shows that foreign plant's output is positively related to both total demand and unit cost difference between home and foreign inputs.

The next decision faced by the MNF is the choice of inputs for foreign plant production. Foreign production is assumed to be given by a Cobb -Douglas production function, that is

$$
\mathrm{q}_{\mathrm{f}}=\mathrm{L}_{\mathrm{f}}^{\alpha} \mathrm{K}_{\mathrm{f}}^{\beta}
$$

The associated costs with foreign production are then given by

$$
\mathrm{C}_{\mathrm{f}}=\mathrm{w}_{\mathrm{f}} \mathrm{L}_{\mathrm{f}}+\mathrm{r}_{\mathrm{f}} \mathrm{K}_{\mathrm{f}}
$$

Where $\mathrm{w}$ and $\mathrm{r}$ are real wage and real user cost of capital respectively. Foreign plant costs are minimized, so that the Lagrangian function is defined as:

$$
\mathrm{L}=\mathrm{w}_{\mathrm{f}} \mathrm{L}_{\mathrm{f}}+\mathrm{r}_{\mathrm{f}} \mathrm{K}_{\mathrm{f}}+\lambda\left(\mathrm{q}_{\mathrm{f}}-\mathrm{L}_{\mathrm{f}}^{\alpha} \mathrm{K}_{\mathrm{f}}{ }\right)
$$

The first order conditions for the cost minimization problem are given by:

$$
\begin{aligned}
& \partial \mathrm{L} / \partial \mathrm{L}_{\mathrm{f}}=\mathrm{w}_{\mathrm{f}}-\lambda \alpha\left(\mathrm{q}_{\mathrm{f}} / \mathrm{L}_{\mathrm{f}}\right)=0 \\
& \partial \mathrm{L} / \partial \mathrm{K}_{\mathrm{f}}=\mathrm{r}_{\mathrm{f}}-\lambda \beta\left(\mathrm{q}_{\mathrm{f}} / \mathrm{K}_{\mathrm{f}}\right)=0 \\
& \partial \mathrm{L} / \partial \lambda=\mathrm{q}_{\mathrm{f}}-\mathrm{L}_{\mathrm{f}}^{\alpha} \mathrm{K}_{\mathrm{f}}^{\beta}=0
\end{aligned}
$$

Dividing equation (11) by equation (12)

and then rearranging yields

$$
\mathrm{w}_{\mathrm{f}} \mathrm{L}_{\mathrm{f}} / \alpha \mathrm{q}_{\mathrm{f}}=\mathrm{r}_{\mathrm{f}} \mathrm{K}_{\mathrm{f}} / \beta \mathrm{q}_{\mathrm{f}}
$$

Taking $\mathrm{L}_{\mathrm{f}}$ from equation (13) and substituting it into (14) yields $\mathrm{K}_{\mathrm{f}}$ as

$$
K_{f}=\left[(\beta / \alpha)\left(w_{f} / q_{f}\right)\right]^{\alpha /(\alpha+\beta)} q_{f}^{1 /(\alpha+\beta)}
$$

Plugging equation (7) into (15) yields the final expression for the desired capital stock at the foreign plant

$$
\begin{aligned}
& \mathrm{K}_{\mathrm{f}} *=\left[(\beta / \alpha)\left(\mathrm{w}_{\mathrm{f}} / \mathrm{q}_{\mathrm{f}}\right)\right]^{\alpha /(\alpha+\beta)}\left[Q_{1} \mathrm{TD}\right. \\
& \left.+Q_{2}\left(\mathrm{c}_{\mathrm{h}}-\mathrm{c}_{\mathrm{f}}\right)\right]^{1 /(\alpha+\beta)}
\end{aligned}
$$

Specifically, the desired capital stock at the foreign plant may be given by

$$
\mathrm{K}_{\mathrm{t}}^{*}=f\left(\mathrm{q}_{\mathrm{f}}, \mathrm{RUC}\right)
$$

where the desired capital stock, $\mathrm{Kt}^{*}$, would depend positively on host country demand (qf) and on the relative unit costs (RUC) between home and host countries. Equation (17) only includes host country demand, which is proxied by per capita GDP.

Equation (17) the desired amount of FDI depends on total market demand (QF) proxy by GDP per capita then the model is expanded to include the impact of remittances, exchange rates, imports and inflation. On the basis of theoretical and experimental studies before, the study would give the proposed model as follows:

$$
\mathrm{FDI}_{\mathrm{it}}=\beta_{0}+\quad \beta_{1} * \mathrm{REM}_{\mathrm{it}}+\beta_{2} * \mathrm{GDPPr}_{\mathrm{it}}
$$
$+\beta_{3} *$ GDPPr*REM $+\beta_{4} * \mathrm{ER}_{\mathrm{it}}+\beta_{5} * \mathrm{INF}_{\mathrm{it}}+$ $\beta_{6} * \mathrm{EXP}_{\mathrm{it}}+\mathrm{u}_{\mathrm{it}}$

\section{Data}

Data consists of information collected for 7 countries (ASEAN-7) including Thailand, Indonesia, Malaysia, the Philippines, Vietnam, Laos, and Cambodia from 2000 to 2013. The dependent variable is FDI net inflows as a percentage of host country GDP (FDI) collected from World Bank data. 
Remittances are collected from World Bank's migration and remittance data and include remittances of residents, income in foreign labor, and property transferred as migrations. This variable is used as independent variable in the model and also divided by GDP (REM). Real per capita GDP (GDPPr) is obtained and calculated from World Bank data. Real exchange rate (ER) and Inflation (INF) data are from the International Financial Statistics (IFS). CPI is collected from the IMF.

\section{Empirical results}

The impact of remittances to FDI through market size hypothesis is tested by two regression models including random effects (RE) and fixed effects (FE). The models include the dependent variable is the ratio of net FDI inflow / GDP and the six independent variable are real GDP per capita (GDPPr), remittances/GDP (REM), real GDP per capita*remittances (GDPREM), inflation (INF), exports/GDP (EXP), bilateral real exchange rate (ER). These variables are taken natural logarithm and then do a first difference to obtain stationary data and show the growth rate.

\section{Table 1}

The results from various regression models

\begin{tabular}{|l|c|c|c|}
\hline Variable name & RE & FE & HACREG \\
\hline$\Delta \operatorname{lnREM}$ & 0.6517 & 0.8652 & $0.6517 * * *$ \\
\hline$\Delta \operatorname{lnGDPPr}$ & 4.396 & 7.653 & $4.396 * *$ \\
\hline $\operatorname{lnREM}$ InGDPPr & -0.0101 & -0.06585 & $-0.0101 * * *$ \\
\hline$\Delta \operatorname{lnER}$ & 1.592 & 3.398 & 1,592 \\
\hline$\Delta \operatorname{lnINF}$ & 0.05503 & 0.06422 & $0.05503 * * *$ \\
\hline$\Delta \operatorname{lnEXP}$ & $0.1041^{* *}$ & $0.1372 * *$ & $0.1041^{* * *}$ \\
\hline Year dummy & yes & yes & yes \\
\hline Significance & $(*) \mathrm{p}<0.1$ & $(* *) \mathrm{p}<0.05$ & $(* * *) \mathrm{p}<0.01$ \\
\hline
\end{tabular}

Based on the Hausman test, RE is chosen. In order to fix heteroskedastic and autocorrelated problems, we use the regression with heteroskedasticity and autocorrelation-consistent standard errors. And the result is revealed in the third column named HACREG.

Real GDP per capita is statistically significant at the $1 \%$, that it increases the motivation to attract FDI. If an economy with GDP per capita is high, multinational firms (MNF) affiliates tend to be attracted to larger markets to exploit economies of scale. The result is consistent with many previous studies such as those conducted by Bajo-Rubio \&
Sosvilla-Rivero (1994); Barrel \& Pain (1996); Brouwer, Paap \& Viaene (2008); Culem (1988); Fedderke \& Romm (2006), and so on. In case other conditions remain unchanged, the net FDI inflows into the economy will increase $4.39 \%$ when per capita GDP raises $1 \%$.

As for direct impact of remittances on FDI, the regression results show a positive significance of $1 \%$. This result is similar to that of study by Basnet (2014) and Garcia (2011) as they found a positive relationship between remittances and FDI. Anyanwu (2011) also finds that remittances have a positive direct impact on attracting FDI. For example, remittances contribute to poverty 
reduction and improve income distribution and quality of life. The rest may be used to improve nutrition, investment in health and education. Also, remittances serve as an aid for recipient households in the event of economic shocks (Chami, Fullenkamp, \& Jahjah, 2005). In some cases, remittances provide capital for households to invest in small businesses, and thus, contribute to economic growth in developing country (Giuliano and Ruiz-Arranz \& 2009). According to Chami, $\mathrm{R}$ et al. (2005), remittances have been reported to improve the balance of payments, which facilitated macroeconomic stabilization. In Southeast Asia, remittances are mainly used for daily consumption, investment in education and health, and help improve the country's balance of payments (ADB, 2006; Jampaklay, 2006). Therefore, the effect of remittances on FDI in Southeast Asia is positive and this supports the theory of ownership-locationinternalization (Dunning, 1998). Accordingly, multinational companies invest overseas to find suitable markets and good labor resources.

The results also show an interesting correlation between FDI, remittances and per capita GDP. The correlation is negative in consideration of indirect channel impact - the impact of remittances to FDI through market size. FDI will decrease $0.01 \%$ when remittances increase and real GDP per capita increase by $1 \%$. This result is similar to the conclusion made by Garcia and Kennedy (2011) that when countries with small economic size have low per capita income, the effect will be negative. This result follows the theory of market size that if a country is large enough to specialize in production factors and minimize costs, it will have potentials to attract FDI.

Export represents the openness of the economy. The results show that when export increases $1 \%$, FDI raise $0.1 \%$, which is similar to research by Barrel and Pain (1996). Obviously, when host countries have policies to encourage exports, they become more active in joining international trade organizations and free trade agreements to reduce tariff and non-tariff barriers to promote the exchange, purchase and sale of goods globally.

Inflation reveals the stability of the economy. The result shows positive effects and statistical significance of $1 \%$. Some previous study like that of (Tuman and Emmert, 2004) indicates that inflation may boost investment, increase aggregated demand of the economy and attract FDI. However, the increase in inflation rate will have an adverse impact on the economy. Within the review period, the article shows positive effects of inflation on changing net FDI attraction.

\section{Conclusions}

This study analyses the effect of remittances and per capita GDP on FDI flows to ASEAN. The most important finding of this research is to confirm the positive effect of remittances on net FDI inflows. Additionally, per capita GDP has a positive and significant effect on net FDI inflows to ASEAN. This is consistent with the theory of market size and the literature about positive relationships between FDI and market size for developing countries

\section{References}

Acosta, P., Calderon, C., Pablo, F., \& Lopez, H. (2008). What is the impact of international remittances on poverty and inequality in Latin America? World Development, 36, 89-114.

Acosta, P., Lartey, E., \& Mandelman, F. (2009). Remittances and Dutch disease. Journal of International Economics, 79, 102-116. 
Adams, R., \& Page, J. (2005). Do international migration and remittances reduce poverty in developing countries? World Development, 33, 1645-1669.

Agosin, M., \& Machado, A. (2006). Openness and the international allocation of foreign direct investment. Economic and Sector Studies Series, RE2 -06-004. Washington, D.C.: Inter-American Development Bank.

Akamatsu, K. (1962). Historical pattern of economic growth in developing countries, The Developing Economic, 1, 3-25

Anyanwu, J. C. (2011). Determinants of Foreign Direct Investment Inflows to Africa, 1980-2007, Working Paper Series $N^{\circ} 136$, African Development Bank, Tunis, Tunisia.

Asia Development Bank. (2006). Worker remittance flows in Southeast Asia. Publication stock No.011806.

Bajo-Rubio, O., \& Sosvilla-Rivero, S. (1994). An econometric analysis of foreign direct investment in Spain, 196489. Southern Economic Journal, 61(1), 104-120.

Barrel, R., \& Pain, N. (1996). An econometric analysis of U.S. foreign direct investment. The Review of Economics and Statistics, 78(2), 200-207.

Barrel, R., \& Pain, N. (1999). Trade restraints and Japanese direct investment flows. European Economic Review, 43, 29-45.

Beine, M., Docquier, F., \& Rapoport, H. (2008). Brain drain and human capital formation in developing countries: Winners and Losers. The Economic Journal, 118, 631-652.

Bengoa, M. \& Sanchez-Robles, B. (2003). Foreign direct investment, economic freedom and growth: New evidence from Latin America. European Journal of Political Economy, 19, 529-545.

Chami, R. et al (2005). Are Immigrant remittance Flows a Source of Capital for Development?. IMF Staff Papers, $52,55-81$

Chami, R.et al (2008). Macroeconomic Consequences of remittances. Occasional Paper, 259, International Monetary Fund.

Cukierman, A., Kalaitzidakis, P., Summers, L., \& Webb, S. (1993). Central bank independence, growth, investment, and real states. Carnegie-Rochester Conference Series on Public Policy, 39, 95-140.

Culem, C., G. (1988). The locational determinants of direct investments among industrialized countries. European Economic Review, 32, 885-904.

Cushman, D. O. (1987). The effects of real wages and labor productivity on foreign direct investment. Southern Economic Journal, 54(1), 174-185

Dornbush, R., \& Fischer, S. (1994). Macroeconomics. 6th ed. New York: McGraw-Hill.

Dunning .J. H. (1998) The eclectic paradigm of international production: a restatement and some possible extensions. Journal of international of business Studies, 19(1).1-3

Garcia, P. A., and Kennedy, P.L.(2011). Foreign direct investment inflows to Latin America and the Caribbean: Remittances and market size." Journal of Ｉnternational Agricultural Trade and Development, 1-21.

Garcia, P. A., Kennedy, P. L. (2011) Foreign Direct Investment Inflows to Latin America and the Caribbean: Remittances and Market Size. Journal of International Agricultural Trade and Development, 7(1).

Garcia, P. A., Kennedy, P. L., \& Ferreira, G. F. (2016). U.S. Foreign Direct Investment in Latin America and the Caribbean: A Case of Remittances and Market Size. Applied Economics, 1-14.

Glytsos, N. P. (2005). The contribution of remittances to growth: A dynamic approach and empirical analysis. Journal of Economic Studies, 32(6), 468-496.

Hem C. Basnet and Kamal P. Upadhyaya. (2014). Do Remittances Attract Foreign Direct Investment? An Empirical Investigation. Global Economy Journal, 14(1), 1-9

IFAD (2014). Sending Money Home to Asia. ISBN 978-92-9072401-8, December 2014. 
Jampaklay, A. (2006). Migrant worker's remittances Cambodia, Lao PDR and Myanmar, Institute for Population and Social Research.

Love, J. H., \& Lage-Hidalgo, F. (2000). Analyzing the determinants of U.S. direct investment in Mexico. Applied Economics, 32, 1259-1267.

OECD (2003), Attracting international investment for development, The OECD catalogue publication.

Pain, N. (1993). An econometric analysis of foreign direct investment in the United Kingdom. Scottish Journal of Political Economy, 40(1), 1-23.

Paola Giuliano \& Marta Ruiz-Arranz, (2005). Remittances, Financial Development, and Growth, IMF Working Paper WP/05/234.

Tuman, J. P., \& Emmert, C. F. (2004). The political economy of U.S. foreign direct investment in Latin America: a reappraisal. Latin American Research Review, 39(3), 9 -29.

World Bank (2011). Migration and remittances fact book 2011, Second Edition.

World Bank (2012). Migration and Development Brief 19, November 20, 2012.

World Bank (2014).World Investment Report 2014: Investing in the SDGs: An Action Plan. 